\title{
Dimensions of expansion for configuring learning spaces in global work
}

Hanna Toiviainen

Faculty of Education and Culture, Tampere University, Tampere, Finland

\author{
Sahara Sadik \\ Institute for Adult Learning, Singapore University of Social Sciences, \\ Singapore, Singapore \\ Helen Bound \\ RID, Institute for Adult Learning, Singapore University of Social Sciences, \\ Singapore, Singapore \\ Pier Paolo Pasqualoni \\ Edith Stein University College of Education, \\ Innsbruck and Stams, Austria, and \\ Padma Ramsamy-Prat \\ Conservatoire National des Arts et Métiers, Paris, France
}

\begin{abstract}
Purpose - Technological innovation and the flexibilisation of labour markets have expanded the pool of workers engaged in globally distributed work. This paper aims to propose an analytical framework to understand and support the productive professional learning of those engaged in global work. Drawing on the theory of expansive learning in the cultural-historical activity theory tradition the study aims to stimulate and enrich the conceptual notion of work as a learning space in the discussion of workplace learning particularly in global work.
\end{abstract}

Design/methodology/approach - Iteration between theory and data is applied to identify the dimensions of expansion for the configuration of learning spaces in global work. Data are drawn from the experiences of 10 professionals selected by purposive sampling in Austria, Italy, the Netherlands and Singapore.

Findings - Six dimensions of expansion are identified as challenging and potentially empowering for professionals' configuration of learning spaces in global work: social-spatial, material-instrumental, moralethical, political-economic, personal-professional and temporal-developmental.

Originality/value - The conceptual framework for the dimensions of expansion of learning spaces provides the broad strokes for reflexive curricula that democratise the learning and development of

(c) Hanna Toiviainen, Sahara Sadik, Helen Bound, Pier Paolo Pasqualoni and Padma Ramsamy-Prat. Published by Emerald Publishing Limited. This article is published under the Creative Commons Attribution (CC BY 4.0) licence. Anyone may reproduce, distribute, translate and create derivative works of this article (for both commercial and non-commercial purposes), subject to full attribution to the original publication and authors. The full terms of this licence may be seen at http:// creativecommons.org/licences/by/4.0/legalcode 
JWL 34,1

professionals in global work, who are currently underserved given the national orientation of vocational education and training and professional development ecosystems.

Keywords Expansive learning, Cultural-historical activity theory, Global work, Learning space, Narratives of learning, Transnational careers

Paper type Research paper

\section{Introduction}

The pathways of individual professionals through global work and the learning potential residing in their experiences are an underexplored area of workplace learning. As Brown and Tannock (2009) highlight, the sweep of neoliberalism since the 1980s extends not only to the global movement of capital and commodities but also to labour. Abetted by flexibilisation of national labour markets and proliferation of communications and platform technologies, the distribution of work across national boundaries takes new forms, seen in the growth of virtual teams and crowdsourcing work, alongside traditional forms such as expatriate assignments and seasonal work for migrant labours. Thus, an engineer in Uganda may perform work as a staff of a transnational corporation, whilst supervisors in Germany design job roles to be filled up by economic migrants and freelance writers in India sign up for work hosted by US-based freelancing sites. The trend towards globally distributed work has been observed to likely increase with the Covid-19 pandemic, as organisational processes sanction remote working that may encourage firms to further invest in developing global digital work processes (Brynjolfsson et al., 2020).

As workers are increasingly engaged in globally distributed work and working with global challenges, it is vital to gain a better understanding of the learning support they may need. The notion of work as a learning space is regarded as powerful for facilitating personal agency and motivation (Kersh, 2015; Ostendorf and Permpoonwiwat, 2017). This article aims to enrich the notion of a learning space by the theory of expansive learning in the tradition of culturalhistorical activity theory (Engeström, 2011, 2015), in which collective practices, social interactions and the development of the self are dialectically interrelated (Stetsenko and Arievitch, 2004). The "dimensions of expansion" (Engeström, 2001) contribute to the discussion of work as a learning space; we focus on individuals' actions for building their resources to interpret and expand the object of their activity, thereby reconstituting themselves and their professional practices in global contexts. Thus, we address the research question:

RQ1. Which dimensions of expansion define professionals' learning space in global work?

We first discuss global work and the issues of learning opportunities and spaces. We define the types of global work and the sampling technique used to collect interview data with 10 professionals. The iterative method of creating and applying the analytical framework is explained. The findings are presented followed by a discussion of the application and implications of our framework, offering it as a tool for professionals to configure their learning spaces in global work. A brief conclusion closes the article.

\section{Global work as learning space}

The learning opportunities of professionals in global work

For professionals in global work, performative practices require crossing multiple cultural, spatial and temporal boundaries. Most research on global workplaces tend to take a cultural lens, focussing on multi-cultural environments in the contexts of multi-national corporations 
(Presbitero and Toledano, 2018; Rozkwitalska, 2017). However, the range of globally distributed work is much wider and the experiences of workplace learning far more nuanced. Mirchandani (2012, p. 23) observes how call centres in India are "sites of colonial domination, patriarchal reification, identity construction, worker resistance, management control and racist expression" that are occurring simultaneously through overt work processes and normative subtexts, as these workers are compelled to connect with their Western clients through mimicry. Toiviainen et al. (2012) analyse the situation of a multinational corporation that is shifting part of knowledge work to its overseas subsidiary with a weak tradition of workplace participation, which requires significant meaningmaking and negotiation of the distant novices' learning. The study by Bound et al. (2019) finds that freelance workers in Singapore's creative industries experience globallydistributed work in contradictory ways; work assignments in advanced economies enable them to boundary-cross to experience sophisticated work practices, whilst the entry of lowcost skilled workers from other Asian countries exacerbates exploitative practices in the local industry. Magaryan (2019) studies crowdsourcing workers and observes that whilst learning from others is an important part of their development, this aspect is deliberately designed out of platform workflows that parcel out discrete work tasks.

It remains an open question of who should be responsible for the learning opportunities of workers in global work and for what purpose. Reflecting on the development of competence of global professionals, Conlon (2004) observes that human resource departments wrestle with supporting individual needs versus those of the organisation. Mustchin (2012) shows that even when British trade unions expand their scope of learning activities to cover migrant workers, it is contingent on the employer and state support. In Canada, immigrant education privileges the socialisation of migrants into Canadian norms, with scant regard for how to tap into immigrants' knowledge and experiences (Shan, 2015). Deeper understanding of the ways in which professionals can exercise agency through configuring their own learning space would support their competence development, wellbeing, as well as agency for social justice. This is an important agenda for research.

\section{Configuration of learning space}

The concept of learning space and the interplay between spaces and learning is receiving increasing recognition (Bound and Rushbrook, 2015; Evans et al., 2011; Ianeva and Tomás, 2021; Kersh and Evans, 2017). Conceptualisations of space have moved well beyond its physical configurations to encompass space as distinct entities constituted by the politics of class, power and economic relations of production; additionally, more recent postmodern approaches direct attention towards a relational concept of space, which focusses on micropractices highlighting the mutuality and interstitial connections within and between spaces (Bound et al., 2018) Patterns of relations exclude or include forms of interaction (Nicolini, 2011), action and activity, creating or constraining affordances for learning. Routines, types of work, forms of production and flow and design of the work and their practices, namely, every day "doings, sayings and relatings" (Schatzki, 2012) constitute and create or reproduce patterns of relations that mediate learning and trajectories (Bound et al., 2018) Such relational understandings of space and learning enable framing of learning and trajectories both in and across spaces to appreciate the potential and opportunity for analysing the development of a sense of belonging (Wyn, 2013), of being and becoming (Holland, et al., 1998; Eteläpelto, 2015).

Yet, more understanding is needed of how the configuration of learning space by learners/ workers may strengthen the opportunity for continuous professional and social development. The theory of expansive learning (Engeström, 2015) in the established frame of cultural-historical activity theory ("CHAT"; Engeström, 2011, 2015) offers us analytical
Configuring learning spaces 
JWL 34,1

possibilities not previously explored and exploited. People in and across communities learn collectively by expanding their object-oriented activities (Engeström, 2015). Their individual actions may contribute to the expansion of any element/s of activity - subject, object, tools, rules, community and the division of labour - to solve the developmental contradictions of activity (ibid.). Being a theoretical construction, contradictions cannot be directly observed in empirical practices; a researcher constructs mediating analytical concepts and looks for culturally shared manifestations of contradictions in the data - expressions of dilemma, disagreements, conflicts, etc (Engeström and Sannino, 2011). The conceptualisation of learning as the expansion of activity, breaking out of given boundaries by dealing with and solving contradictions, is here extended to the study of learning space, particularly to define the dimensions of expansion for the support of global workers' learning opportunities.

Over a working lifetime, global workers not only work across organisational and international boundaries but many move variously through differing employment relations permanent employee, consultant, freelance or casual, short-term contract, etc. As such, global workers (our subjects) become members of highly varied practices and communities, and thus, their activity systems - the object, tools, rules, etc., as well as the relations of power and agency involved - change over space and time. Systemic conditions may "exert tremendous influence on individual actions" (Engeström, 2001, p. 298) such as on global workers' actions for configuring their learning space. They, in turn, exert agency to deal with the conditions and expand the boundaries of learning (Daniels et al., 2013). Identity development is intrinsically a part of these interactions. Holland et al. $(1998$, p. 5) define that identity "combines the intimate of the personal world with the collective space of cultural forms and social relations". Identities are lived in and through activity, thus developing in social practice (ibid.).

To recount, the authors are bringing together a number of concepts that spin out from each other: namely, patterns of relations in learning spaces and their contribution to trajectories and identities of global workers; and an appreciation of the theories of objectoriented activity and expansive learning. As global workers (or indeed workers in general) shape, configure or create the working-learning spaces, they inevitably experience and work on tensions that manifest the developmental contradictions evolving in the transformation of activity (Engeström, 2011; Engeström and Sannino, 2011). An activity may constitute one or many learning spaces, suggesting a need for an analytical tool that enables the researcher to investigate the multidimensionality related to the trajectories of global workers. Engeström's (2001) dimensions of expansion of the object - social-spatial ("who else should be included"?), anticipatory-temporal ("what previous and forthcoming steps should be considered"?), moral-ideological ("who is responsible and who decides"?) and systemicdevelopmental ("how does this shape the future of our activity"?) - offer such a tool.

In this article, we revisit and reformulate the object-oriented dimensions to trace the tensions and expansions related to the configuration of learning space in global work. We posit that the implementation of the dimensions of expansion allows us to ask questions about learning space. Here, the configuration of learning space mediates professionals' relationship with the object of activity. In Engeström's (2001) case, it was decision-making mediating the patient's care as the object of a health-care network. We recognise that the dimensions analysed in our study address a heterogeneous constellation of objects and that the objects of activity are multi-layered (Toiviainen, 2007; Toiviainen and Vetoshkina, 2018).

\section{Methods and data \\ Sampling of data}

The review of academic literature on global work (summarised in the background sections, Brown and Tannock, 2009; Brynjolfsson, et al., 2020; Conlon, 2004; Magaryan, 2019; Mirchandani, 2012; 
Presbitero and Toledano, 2018), helped us identify two empirically grounded dimensions that capture both the diversity of employment arrangements (contingent - permanent work) and the socio-spatial sites (relocation/travel - virtual) and define four archetypes (Figure 1). This four-field frame provided us a technique of purposeful sampling (Emmel, 2013), which meant identifying the respondents (Table 1) so that they cover all four quadrants (Figure 2).

\section{Conduct of interviews}

The researchers conducted narrative interviews (Clandinin and Connelly, 2000) asking the respondents to reflect on their professional careers and life trajectories, workplace experiences and affordances for learning. The frame of interviews was unstructured containing open questions that let the informants choose the course of their accounts. This kind of data collection was meant to serve multiple research interests regarding learning in global work. In other words, narrative interviews were not driven by theorising of learning space. By making wider use of data possible our strategy reflects the established practices of reusing qualitative data (Bishop and Kuula-Luumi, 2017).

The interviews were conducted mostly face-to-face between 2017 and 2019 and transcribed verbatim. Informed consent was obtained from all interviewees at the beginning of the interview. The researcher in charge of a given interview produced a detailed summary of the transcription, which formed the material analysed by the research team.

\section{Method of analysis}

Academic literature was reviewed to understand the construction of learning space. This understanding directed attention to phenomena such as: crossing cultural, spatial and temporal boundaries, experiences of power relations, identity construction, management control, workplace participation, learning from others, supporting individual and organisational needs and exercising agency for competence development, well-being and social justice (review above). The research team monitored the data and collectively specified and extracted the data excerpts for the analysis of the dimensions of expansion.

The next phase of analysis started with individual work. Researchers scrutinised the four dimensions of expansion defined by Engeström (2001) and tentatively applied them to the data. Whilst doing so they made notes and proposals for reformulations and additions to the dimensions. The whole team then discussed these observations. We moved iteratively

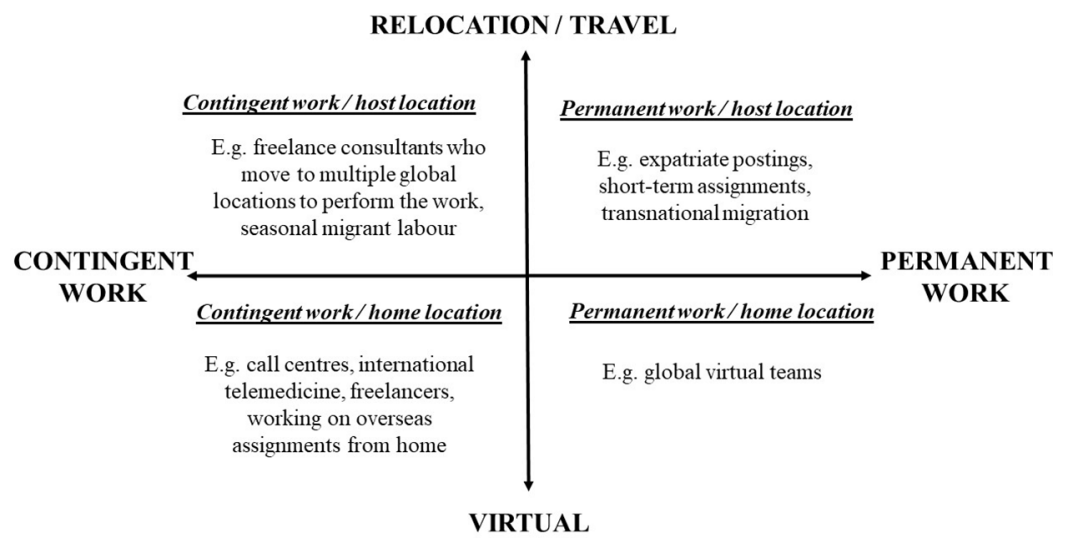

\section{Configuring learning spaces}

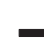

(1)


Name Professional experiences in global work

Alessandro A native of Kenya, Alessandro came to Italy after his graduation from high school to work as a volunteer in an NGO helping refugees. He then pursued university studies in education in Italy. Upon graduation, he held two part-time appointments in the same NGO, as well as another refugee centre. He is fluent in English and Italian, speaks some French and understands two dialects

Scarce work opportunities in Bangladesh prompted Ehsan to seek out work in Singapore as a construction worker at the age of 25. Unlike many of his peers, Ehsan is a diploma holder and speaks good English, which earns him the favours of many of his employers. Despite being recognised for his capabilities, the restrictive employment conditions as a migrant worker in Singapore mean that development pathways for Ehsan are limited

Emily Emily completed her first academic studies in her home country in the USA, whilst helping in a family business. She moved to Germany for work experience and combined it with study. Emily worked for a global firm, specializing on intercultural training. She then went to Thailand with her son, to complete her $\mathrm{PhD}$ with a German university whilst working as a lecturer at a Thai university. After graduation she worked as a lecturer at universities in the Netherlands

Georg An Austrian, Georg started out as an apprentice cook working in five European countries before he was selected to be a chef at a prestigious hotel. He was then rotated to eight countries in Asia and the Middle East (Singapore, Indonesia, Israel, Oman, United Arab Emirates, India, Hong Kong and China). Returning to Austria, he first worked as a FandB manager in a large hospital kitchen. He then opted for seasonal work as an instructor preparing disadvantaged migrant youths to become cooks and as a skiing instructor

Mei Yan A Chinese national, Mei Yan first came to Singapore as a university intern attached to a retail outlet. She then worked briefly in a travel company in China before deciding to return to Singapore to work in a traditional Chinese medicine company. She soon switched to become a full-time freelancer specialising in Chinese language courses for the business community in Singapore. Feeling that she was stagnating professionally, she was seeking new qualifications to switch to a marketing role

Peter Peter began his working life as a teacher in Spain. He then joined an international publishing firm, where he worked in different capacities in Spain and Portugal and subsequently studied in England to become an editor. Peter was then transferred to Japan where he spent three years with the family before relocating to Singapore. After a total of 23 years with the publishing firm, he left and took up an offer with another publishing firm as product director for Asia. However, the company underwent a structural change, leaving Peter free to pursue his business consultancy career

Quah A Singaporean who pursued an architecture degree in Australia, Quah worked as an architect briefly before joining an agency handling Asian student recruitment. Based in Singapore, he provided education guidance to potential students and their families, often travelling to Asian locations to meet up with them. Subsequently, he was laid off and tried different options in the same field

Susannah A Singaporean, Susannah is a tax consultant with the Singapore subsidiary of a big four accounting firm. In recent years, part of her work has been off-shored to India, which required the company to establish new working practices digitally between the Singaporean and Bangalore offices. Susannah found herself playing a new role as an informal mentor and coach to her Bangalore co-workers, who struggled to meet the expectations of their Singaporean co-workers

\section{Vincenzo A native of Italy, Vincenzo graduated from university as an educator and worked in his} hometown for 7 years as a refugee educator. Feeling that local and governmental policies were against the profession's efforts to educate refugees, he left and travelled to India for a year. He came back to take care of his father. He continues to work part-time as a refugee educator and holds another part-time position delivering food for seniors

Table 1.

Xin

Experiences in global work of 10 respondents
Xin is a Singaporean freelance graphic designer with work experience in many educational publishing firms in Singapore. The biggest professional challenge for her was as a manager in the Singapore subsidiary of a major European educational publishing house, where she had the responsibility of handling the business process outsourcing of certain parts of the work from Singapore to India 


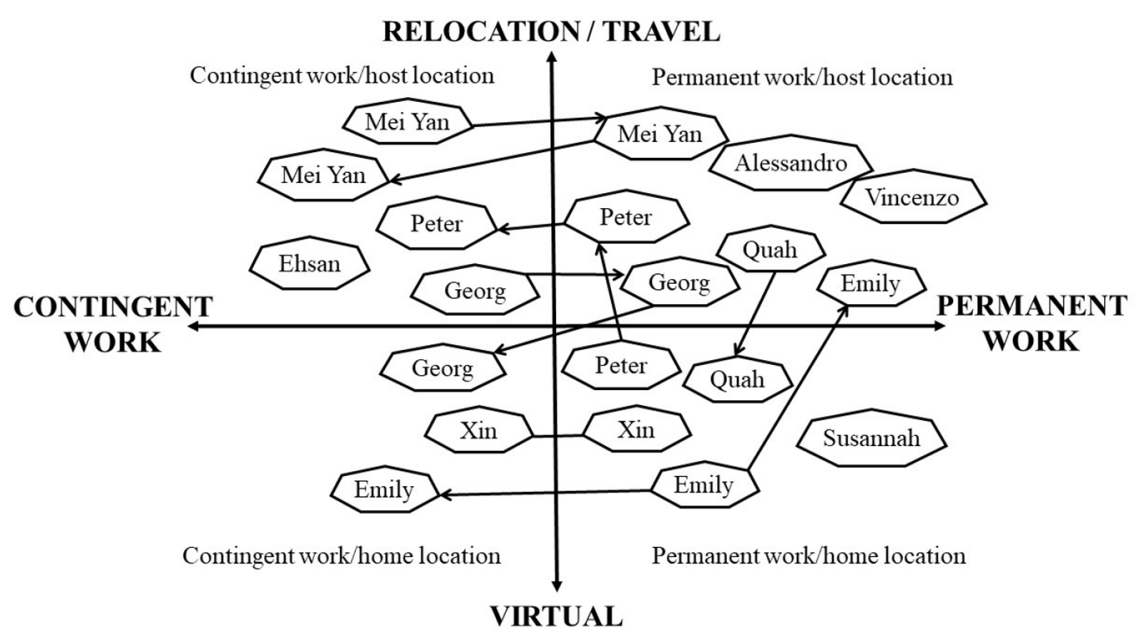

\section{Configuring learning spaces}

Figure 2.

Trajectories of respondents

between theory and data until we were satisfied that all learning-related key dimensions have been captured.

Based on the theory of expansive learning (Engeström, 2015) we defined interpretive criteria to identify the expansions and contradictions in the informants' accounts of learning space. For expansions, such markers are: narrations of learning, development, creative solutions, productive changes of the object, and widening the horizon of actions in various ways. For contradictions, we looked for narrations of problems, criticism, conflicts, quests for change and the need for novel solutions and being unable to move on in the desired direction.

Final step of analysis resulted in the description of the dimensions of expansion, which are presented in the next section of findings. The excerpts from professionals' narratives of experiences in global work are used to illustrate each dimension followed by a summarising definition. Expansions and contradictions are characterised in an ideal-typical manner, partly as hypothetical suggestions. In the application presented in the final discussion, they will be concretised through the case of one of our informants, Xin.

\section{ASEM as the context of research}

ASEM Education and Research Hub for Lifelong Learning (ASEM Education and Research Hub for Lifelong Learning, 2021) is a network of Asian and European higher education institutions. Conducted as part of the Asia-Europe Meeting (ASEM) cooperation, our investigations focussed on the Asian and European contexts. We reached out through our networks to respondents in Austria, Italy, The Netherlands and Singapore. ASEM offered the authors an opportunity to meet and discuss in early phases of research. The authors designed the research project, collected the data and carried out the analysis independently of the hub organisation (https://asemlllhub.org/).

\section{Findings}

This section presents the research findings. Analytical iterations across theory and data produced six dimensions of expansion for the configuration of learning space (Table 2). 
Dimension of expansion Questions

Keywords

Social-spatial With whom, for whom or under whom the person works?

What collaborative contacts and spaces are created?

What efforts to cross boundaries are made?

Materialinstrumental

What are physical/geographical work environments like?

What material conditions and tools are implemented for expanding the learning space?

What are the instruments and instrumental constraints of agency?

Moral-ethical

Who is responsible for good work?

What ethical issues and constraints do a person's face and what are the potentially expansive solutions?

Political- Who decides, who has power?

economic What possibility to influence does a person possess?

How do the rules of democracy work?

Personal- How does the person position her/himself with her/ professional his work and career?

Temporal- What is the time perspective of a person's work?

Developmental How does the person assess his/her development in the past, present and future? What are the turning points?
Boundary crossing

Collaboration

Community building

In/formal gatherings

Knowledge creation

Networking

Social relationships

(Material) conditions of workplace

Tools of work

Working infrastructures

Use of tools (designing,

implementing and developing)

Choices

Consequences

Decisions

Legal protection

Professional ethics

Responsibility

Right and wrong

Values

Decision-making

Economic structures

Inequality

Legislation

Manager-employee relations

Power

Workers' rights

Workplace democracy

Capacity building

Career planning

Expertise

Identity formation

Meaning-making

Professional reorientation

Change

Development

Experiences (over the time)

Reflection (past, present and future)

Turning points

\section{Social-spatial dimension}

Alessandro works in a refugee centre guiding the residents to live together family-like to balance their difficult situations. The house becomes a study place when the students put their books and notes on the dining table and ask questions about the lessons they have taken in the language centre. Alessandro helps them, but does not see himself as a teacher, his task is "not pedagogical, it's just practical".

Alessandro's colleague, Vincenzo, provided the residents with training and networking possibilities in the centre. His social-spatial intervention was, however, not in line with local policies: after the six-month period, if migrants could not claim political asylum, they were 
expelled. "[So] you see them around the station and you can do nothing for them". Vincenzo was frustrated and, partly because of his limited possibilities to help, left his position to spend a sabbatical year.

The expansive use of social relationships and spaces means exceeding the socio-spatial boundaries originally given to or chosen by professionals. Alessandro's expansive actions created a "third place" (Oldenburg, 1999; Azam, et al., 2015) to the residents referring to informal public gatherings crucial for the community vitality and democracy. Vincenzo's expansive efforts for refugees' networking were rejected by local authorities.

Social-spatial dimension represents:

- expansion of collaborative relationships, crossing boundaries of experience, expertise and physical space and networking to solve problems and create knowledge; and

- contradiction: collaboration, networking vs social isolation and disintegration.

\section{Material-instrumental dimension}

Ehsan had received education and gained proficiency in oral and written English, which positioned him with tools most foreign construction workers do not have. Language was a tool that expanded the infrastructure for communication channels between workers and the boss. Lodgings are also an important part of infrastructure mediating foreign workers' ability to contribute productively. Ehsan's lodgings in Singapore were well below standard; he contracted dengue and landed in the hospital. He decided to return to Dhaka, only to travel back to Singapore to try again. Despite poor material conditions he struggled to expand on his material-instrumental working infrastructures for urban living and learning.

Peter works globally travelling a lot, relying on tools such as his computer, phone and conferencing. He describes digital tools as being an extension of his body. His access to material-instrumental resources, however, is not necessarily expansive, given the impact that "being on 24/7" has on the human body and family life.

Professionals' work entails developing and implementing tools of work and building working infrastructures. Cultural-historically interpreted, the object of work is tool mediated; the development of tools is an aspect of human development and learning (Vygotsky, 1978). Therefore, workers' use and crafting of their tools and infrastructures matter in workplace learning (Toiviainen et al., 2009; Seppänen and Toiviainen, 2017) and forms the conditions for the material-instrumental configuration of learning space.

Material-instrumental dimension represents:

- expansion in terms of designing and redesigning, implementing and developing tools and infrastructures of work that can be shared in community; and

- contradiction: innovation, creativity vs scarce and limited resources.

\section{Moral-ethical dimension}

As an international student recruiter, Quah saw his role as an educational counsellor. However, when working for a local private institution he was positioned as a salesperson, which went against his beliefs and values about education. He found the approach unethical, involving issues marginal to potential students' educational prospects such as aggressive use of social media for marketing purposes.

\section{Configuring learning spaces}


JWL 34,1

Susannah was all but satisfied with the management's superficial logic to avoid a high turnover rate in an offshore subsidiary unit, framed as: "these people are really a very sensitive group of people and they can just leave the firm without telling you"; "they require gentle handling". Susannah reframed "gentle handling" by paying special attention to both verbal and non-verbal expressions in communicating with her offshore colleagues as individuals. Her solution is an extension of caring "gestures" analysed in research involving therapeutic education (Ramsamy-Prat, 2015; 2019).

Workers struggle with questions of right and wrong; the accountability and responsibility in human action. Professionals make choices weighing up the consequences of alternative courses of action by relating them with community values and professional ethics. The construction of the moral-ethical dimension of learning space mirrors the values and power structures of the field of work or profession. Expanding efforts often seem to bring underlying conflicts of interest into daylight (Fenwick, 2016). Rather than negotiation and appeal to legal protection, our informants' narratives convey solutions based on individual courage and sometimes a decision to exit.

Moral-ethical dimension represents:

- expansion in terms of responsibility and consideration of consequences; whom this concerns or should concern?

- contradiction: free, negotiated vs constrained and given choice.

\section{Political-economic dimension}

Georg felt privileged to be part of a selected talent pool groomed for deployment across the hotel chain globally. In the Singapore hotel kitchen, he was able to set standards and demand professional commitment and compliance from his team. The contrast in different parts of the world was striking and gave Georg hard lessons back in Austria where the manager-subordinate relationship was less hierarchical and his attempts at introducing new practices were not readily supported by chefs.

Ehsan's profession as a Bangladeshi migrant worker in Singapore's construction industry meant that he was significantly disempowered and with limited employment rights. However, recognised for his English prowess, he was entrusted to take on higher-level tasks. Even after a falling-out with his boss, he continued to enjoy informal power due to his competence such that he had other senior staff speaking up for him and seemed confident to secure employment in other companies.

Professionals narrate power relations, workers' rights and economic structures at the workplace including workplace democracy, workers' input into the decisions that affect them, compensation and enter/exit opportunities (Jacob and Neuhäuser, 2018). Manageremployee relationships are structured by state-level legislation but also on local and firmlevel policies (Holm and Lorenz, 2015). Learning space is shaped by the hidden curriculum at the workplace (Margolis and Romero, 1998) that may maintain and reproduce existing inequalities.

Political-economic dimension represents:

- expansion towards fair workplace practices; equality in social, economic, educational and well-being aspects of work; and

- contradiction: powers and influence vs disempowerment. 
After having painfully given up on his notion of climbing a traditional career ladder in the food and gastronomy industry, Georg grasped the opportunity to train disadvantaged young people to become cooks. This and work as a ski instructor were for him meaningful ways of sharing his special skills. For Georg his experiences represented a personalprofessional expansion towards managing diversity.

Emily built her identity amidst conflicting pressures of being a good single mum and performing a successful career. Societal and employer expectations weighed heavily on her sense of managing to combine parenting and career in global work. Emily described her career as chaotic until she entered international academia and postgraduate studies where "it all came together".

Practically all our informants describe how they have built capacities and gained expertise; some have had to reorient themselves many times. The narratives display resilience and creativity in adapting to new circumstances and changing work environments typically through events, in which personal and professional intertwine. Professionals construct their identities when positioning themselves with work and its meaning in their life stories. Transnational contexts give rise to "spatial struggle" in the formation and expansion of professional identities (Kostogriz and Peeler, 2007).

Personal-professional dimension represents:

- expansion of capacities, resources, professional fields of activity, life choices; and

- contradiction: continuity vs discontinuity.

\section{Temporal-developmental dimension}

Mei Yan was a tour planner in China, before coming to Singapore to work in a traditional Chinese medicine centre and then teaching Mandarin to young children and then business Mandarin to senior executives. She never planned for these professional turning points that contributed to a sense of stagnation and uncertainty of what she should do next. At the time of the interview, she had decided to apply for a prestigious Masters in Business Administration in Shanghai to restart her career, seeking to re-enter corporate life as marketing personnel.

We propose the temporal-developmental dimension of learning space as a "summative" trajectory of a professional's experiences and learning efforts shaped by turning points on multiple dimensions. The temporal-developmental perspective supports a learner's reflection on the contradictions and expansions in the past, present and future developments, which is defined as a necessary element of adults' learning (Engeström, 2015).

\section{Discussion}

\section{Application of the analytical framework of learning space}

To demonstrate how the dimensions of expansion may potentially allow professionals in global work to configure and reconfigure their learning space we apply them to the case of one of the respondents, Xin. This is a hypothetical example in which we discuss the potential of the six dimensions of expansion for the reconfiguration of her learning space during what she called the most challenging period of her professional life (Case description). 


\section{Case: Xin}

A passionate graphic designer, Xin was appointed to a managerial position in a Singapore subsidiary of a European publishing house and tasked to facilitate offshoring from Singapore to India as part of the firm's cost-cutting measures. This required her to make tough decisions. She had to find a way to optimise the workflow between Singapore and India as there was unhappiness in the Singapore office with the quality of work from the Indian design house. She also had to decide which job roles in the Singapore office had to be axed.

On visiting the Indian design house, Xin observed the Taylorist work design; a few star designers were creating templates, which were then mass-produced by shift work designers. The latter lacked autonomy and even adequate physical workspace to fit their mouse. Instructions from clients were pushed out from the top down and distributed across a chain of workers, leading to misunderstandings and constant revisions. She did not think that this was a conducive environment for producing good, artistic work. However, she felt she had to make offshoring effective (a corporate directive) and out of compassion to help some Indian workers keep their job.

To optimise the workflow, Xin's solution was to get the Indian design house to select a fixed group of individuals who would work with the Singapore office and train them to meet the desired standards. Her next step was to decide on who to lay off from the Singapore office. Reasoning that graphic designers could also take on project management roles, she decided to lay off the project managers. This was strongly resisted by the Singapore graphic designers who saw the additional role as work intensification. She quit her job during this period as she felt she could no longer balance her professional and personal lives well.

Xin changed to freelancer work. She later learned that tensions persisted in the Singapore office, causing the bosses to reinstate the project managers and to give them more power to oversee the work of the graphic designers in Singapore and India. She viewed this as a significant loss to the professional autonomy and identity of graphic designers.

Xin's experiences of struggling with and solving the tensions can be interpreted as a process of configuring and potentially expanding on her learning space. To make sense of the tensions identified and their expansive potential on various dimensions (Figure 3), we first raise the question about the object of activity (Engeström, 2001), the graphic design services provided to customers. The analysis reveals the contradiction emerging between the personally meaningful object, that of professionally high-quality design and the organisational object of increasing profitability through offshoring design work. By analysing the contradiction, Xin may be in a better position to deal with the dilemma of acting under conflicting pressures of her dual role as a designer-manager, further pushing her understanding of the nature of the manifest tensions as part of her learning space.

Xin's reflections may additionally bring out expansive interrelationships between the dimensions of expansion. For example, would an expansion on the socio-spatial dimension in terms of seeking support from her professional network enable expansion of the moralethical dimension putting her in a better position to negotiate the negative consequences of offshoring for the staff? Interrelations are supported by Engeström's (2001, p. 286, 287) definition of the "moral-ideological" expansion in specialised health care: rather than each 


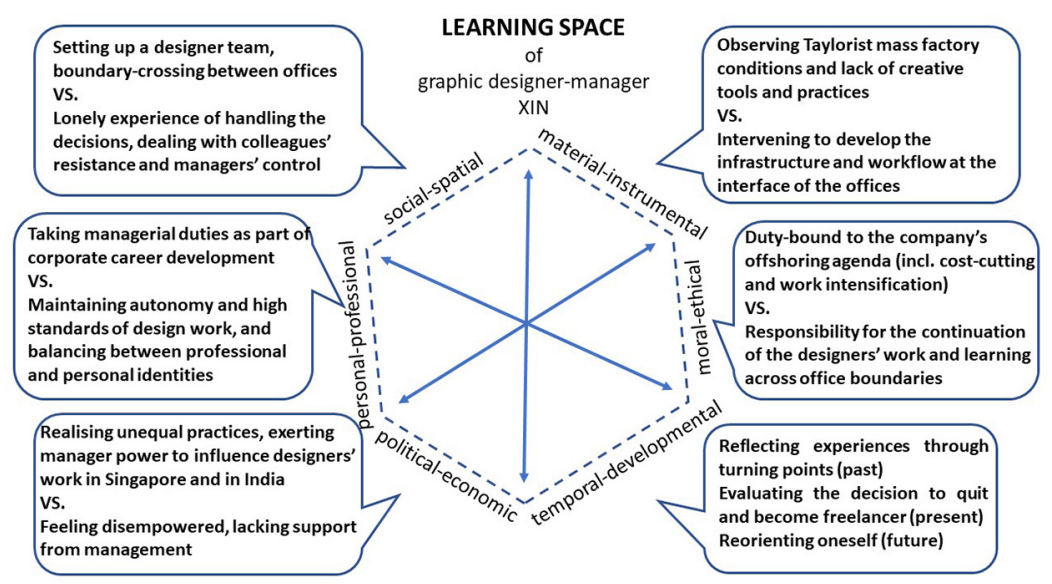

\section{Configuring learning spaces}

individual professional being responsible only for the care she or he is giving, all practitioners involved take responsibility for the patient's care trajectory. In our framework, the moral-ideological expansion (all are responsible) has implications to the social-spatial dimension (communication amongst practitioners) and even political-economic dimension, as Engeström points out, "it is not anymore automatically given that the highest-ranking specialist alone has absolute power to determine the course of the care" (ibid.). Reconfiguring the learning space by interrelating potential expansive actions across the dimensions would allow for the reimagining of new possibilities and lines of action.

The analysis of the tensions makes the boundaries of learning space in global work visible such as the inequality of the learning opportunities across the sites of the company. As a manager, Xin might be in a position to not only reconfigure the personal but also collective learning space in both Singapore and India. The underlying contradictions tentatively formulated for each dimension in the first part of this analysis may expand Xin's perspective to underlying tensions and their potential solutions. For example, the contradiction of the politicaleconomic dimension that was defined between powers/influence and disempowerment is reflected in Xin's exerting managerial power to influence designers' work but feeling disempowered and lacking managerial support. Xin's social-spatial struggle with team building and boundary-crossing, on the one hand, and lonely work and workers' resistance, on the other hand, manifests the contradiction between collaboration/networking and social isolation/disintegration. Xin's case can be used to "validate" and further elaborate on the contradictions of these and remaining dimensions of expansion; between innovation, creativity vs scarce, limited resources (material-instrumental), free, negotiated vs constrained, given choice (moral-ethical), continuity vs discontinuity (personal-professional) and the contradictions of the temporal-developmental, biographic turning points.

After this application exercise, the next step for the research team is two-fold. Firstly, the data set needs to be expanded, as our framework will need to be validated and enhanced by involving more workers from more locations and taking up a wider range of global work. One observation we have not discussed in this article is the involvement of many respondents in education, training or teaching either formally or informally. Examples are Susannah coaching her Indian colleagues, Mei Yan guiding non-Chinese business leaders to connect with Chinese culture and Vincenzo and Alessandro supporting the education of 
JWL 34,1

refugees. The educational aspect of global work needs to be studied more in the future and properly captured in the dimensions of expansion.

Secondly, we will need to test the applicability and efficacy of the analytical framework in facilitating the reflections of professionals in global work for the purpose of reconfiguring their learning space. This similarly needs to be done by involving global workers from a range of locations and professions. In addition, addressing global work organisations allows us to explore the practical and organisational conditions of the implementation of the framework developed in this study and thereby raise awareness of workers' learning needs.

\section{Implications}

For increasing groups of professionals, global work constitutes the space for workplace learning. Thus, there is a well-grounded need to research global work as a site of learning to support these workers' professional development in a way that fully recognises their global contexts. This is not readily provided by traditional vocational education and training (VET) offerings by national providers that tend to have a local orientation (Shan, 2015), nor by employers who tend to restrict such opportunities only to a distinct elite or deliver material based on organisations' needs, rather than allowing learners to determine the direction of their learning (Conlon, 2004).

It makes little sense to argue for a global model for the development of global workers, given the range of context-specific needs they have, their biographies and prior knowledge as demonstrated in our sample. In this regard, the framework of dimensions of expansion outlined offers broad strokes for developing reflexive curricula. Facilitated by acquainted trainers, professional workers are engaging in the reflexive practice of configuring and reconfiguring their learning spaces on multiple dimensions of expansion. The contradictions and opportunities inherent in any workplace context are potentially empowering and may enable new horizons of action, contributing to a transformative process (Sannino, et al., 2016).

We are, therefore, arguing for the democratisation of learning opportunities for global workers particularly those who are disadvantaged, marginalised and under-represented. Rather than a fixed curriculum as it is typically offered in cross-cultural workshops (Presbitero and Toledano, 2018), our proposed framework may support learners in designing their own learning spaces that attend to their full range of needs be they professional, emotional, social, cultural and more. Such a reflexive curriculum can be recontextualised in a variety of ways by multiple providers. Beyond the workers themselves, the dimensions of expansion could benefit employers and organisations in offering socially responsible human resource management (Shen and Benson, 2014) and international non-government organisations (NGOs) in enhancing life-long learning opportunities including the ASEM Lifelong Learning Hub that provided a setting for this study. With the Covid-19 pandemic accelerating trends for companies to distribute work remotely (Brynjolfsson et al., 2020), there is a pressing need to facilitate reflection around the work design and social relations to enable expansive learning. A major challenge remains for both academic research and professional practices to work against the generation of potentially disempowering global work.

\section{Conclusion}

This article discusses the learning spaces for professionals engaged in global work, highlighting the complexity and diversity of such work, as well as the challenge of identifying and supporting workplace learning. Six dimensions of expansion are offered by way of a reflexive curriculum to empower global workers to configure and reconfigure their learning space and exercise agency to undertake new lines of action. The democratisation of learning and support for global workers represents a challenge given the nationally biased orientation of vocational education systems. We call for a broad set of actors in society, 
including employers, training providers, unions, NGOs and professional bodies, to facilitate the delivery of reflexive curricula for both workers and their members to allow for global work that is empowering and respectful of the dignity of every worker.
Configuring learning spaces

\section{References}

ASEM Education and Research Hub for Lifelong Learning (2021), available at: https:/asemlllhub.org/ (accessed 26 November 2020).

Azam, M., Chauvac, N. and Cloutier, L. (2015), "Quand un tiers-lieu devient multiple: chronique d'une hybridation”, Recherches Sociologiques et Anthropologiques, Vol. 46 No. 2, pp. 87-104.

Bishop, L. and Kuula-Luumi, A. (2017), "Revisiting qualitative data reuse: a decade on", Sage Open, Vol. 7 No. 1, pp. 1-15, doi: 10.1177/2158244016685136.

Bound, H., and Rushbrook, P. (Eds.) (2015), “Towards an expanded understanding of workplace learning”, The Context of Singapore, LAL, Singapore, available at: www.ial.edu.sg/content/dam/projects/tms/ ial/Research-publications/Books/Towards $\% 20 \mathrm{~A} \% 20 \mathrm{New} \% 20$ Understanding $\% 20$ of $\% 20$ Workplace \%20Learning.pdf

Bound, H., Chia, A. and Lee, W.C. (2018), "Spaces and spaces in between' - relations through pedagogical tools and learning", Choy, S., Wärvik, G.B. and Lindberg, V. (Eds.) Integration of Vocational Education and Training Experiences: Purposes, Practices and Principles, Springer, Dordrecht, pp. 243-258.

Bound, H., Sadik, S., Evans, K. and Karmel, A. (2019), How Non-permanent Workers Learn \& Develop, Choy, S., Wärvik, G.B. and Lindberg, V. (Eds.) Challenges and Opportunities, Routledge. London,

Brown, P. and Tannock, S. (2009), "Education, meritocracy and the global war for talent", Journal of Education Policy, Vol. 24 No. 4, pp. 377-392.

Brynjolfsson, E., Horton, J.J., Ozimek, A., Rock, D., Sharma, G. and TuYe, H. (2020), "Covid-19 and remote work: an early look at US data", Working Paper 27344, National Bureau of Economic Research Working Series, Cambridge, MA, available at: www.nber.org/papers/w27344

Clandinin, D.J. and Connelly, F.M. (2000), Narrative Inquiry: Experience and Story in Qualitative Research, Jossey-Bass, Sans Francisco.

Conlon, T.J. (2004), "A review of informal learning literature, theory and implications for practice in developing global professional competence”, Journal of European Industrial Training, Vol. 28 Nos 2/3/4, pp. 283-295.

Daniels, H., Edwards, A., Engeström, Y. and Gallagher, T.L.S.R. (Eds), (2013), Activity Theory in Practice: Promoting Learning across Boundaries and Agencies, Routledge.

Emmel, N. (2013), Sampling and Choosing Cases in Qualitative Research: A Realist Approach, Sage, London.

Engeström, Y. (2001), "Making expansive decisions: an activity-theoretical study of practitioners building collaborative medical care for children", in Allwood, C.M. and Selart, M. (Eds), Decision Making: Social and Creative Dimensions, Springer, Dordrecht, pp. 281-301.

Engeström, Y. (2011), "Activity theory and learning at work”, in Malloch, M., Cairns, L., Evans, K. and O'Connor, B.N. (Eds), The SAGE Handbook of Workplace Learning, Sage, London, pp. 86-104.

Engeström, Y. (2015), Learning by Expanding: An Activity-Theoretical Approach to Developmental Research, 2nd ed., Cambridge University Press, Cambridge.

Engeström, Y. and Sannino, A. (2011), "Discursive manifestations of contradictions in organizational change efforts: a methodological framework", Journal of Organizational Change Management, Vol. 24 No. 3, pp. 368-387.

Eteläpelto, A. (2015), "The role of work identity and agency in workplace learnin", Bound, H. and Rushbrook, P. (Eds.) Towards an Expanded Understanding of Workplace Learning, The Context of Singapore, IAL, Singapore, pp. 36-53. , available at: www.ial.edu.sg/content/dam/projects/tms/ial/ Research-publications/Books/Towards $\% 20 \mathrm{~A} \% 20$ New $\% 20$ Understanding $\% 20$ of $\% 20$ Workplace $\%$ 20Learning.pdf 
JWL 34,1

Evans, K., Guile, D. and Harris, J. (2011), "Rethinking work-based learning: for education professionals and professionals who educate", Malloch, M. Evans, K. and O'Connor, B.N. (Eds), The SAGE Handbook of Workplace Learning, Sage, London, pp. 149-161.

Fenwick, T., (2016), Professional Responsibility and Professionalism, A Sociomaterial Examination, Routledge, London.

Holland, D., Lachicotte Jr, W., Skinner, D. and Cain, C. (1998), Identity and Agency in Cultural Worlds, Harvard University Press, Cambridge.

Holm, J.R. and Lorenz, E. (2015), "Has 'discretionary learning' declined during the lisbon agenda? a cross-sectional and longitudinal study of work organization in european nations", Industrial and Corporate Change, Vol. 24 No. 6, pp. 1179-1214.

Ianeva, M. and Tomás, J.-L. (2021), "Guest editorial, Special issue: rethinking work through (work) spaces”, Journal of Workplace Learning, Vol. 33 No. 1, pp. 1-9, doi: 10.1108/JWL-02-2021-170.

Jacob, D. and Neuhäuser, C. (2018), "Workplace democracy, market competition and republican self-respect", Ethical Theory and Moral Practice, Vol. 21 No. 4, pp. 927-944.

Kerosuo, H. and Engeström, Y. (2003), "Boundary-crossing and learning in creation of new work practice", Journal of Workplace Learning, Vol. 15 Nos 7/8, pp. 345-351, doi: 10.1108/13665620310504837.

Kerosuo, H. and Toiviainen, H. (2011), "Expansive learning across workplace boundaries”, International Journal of Educational Research, Vol. 50 No. 1, pp. 48-54, doi: 10.1016/j.ijer.2011.04.009.

Kersh, N. (2015), "Rethinking the learning space at work and beyond: the achievement of agency across the boundaries of work-related spaces and environments", International Review of Education, Vol. 61 No. 6, pp. 835-851.

Kersh, N. and Evans, K. (2017), "Exploring working places and self-generated learning spaces: concepts, perspectives and cases from the United Kingdom", in Ostendorf, A. and Permpoonwiwat, C.K. (Eds), Workplaces as Learning Spaces - Conceptual and Empirical Insights, Innsbruck University Press, Innsbruck, pp. 15-34.

Kostogriz, A. and Peeler, E. (2007), "Professional identity and pedagogical space: negotiating difference in teacher workplaces", Teaching Education, Vol. 18 No. 2, pp. 107-122.

Magaryan, A. (2019), "Workplace learning in crowdwork: comparing microworkers' and online freelancers' practices”, Journal of Workplace Learning, Vol. 31No. Vol. 4, pp. 250-273.

Margolis, E. and Romero, M. (1998), "The department is very male, very white, very old, and very conservative': the functioning of the hidden curriculum in graduate sociology departments", Harvard Educational Review, Vol. 68 No. 1, pp. 1-33.

Mirchandani, K. (2012), Phone Clones: Authenticity Work in the Transnational Service Economy, Cornell University Press, New York, NY.

Mustchin, S. (2012), "Unions, learning, migrant workers and union revitalization in britain", Work, Employment and Society, Vol. 26 No. 6, pp. 951-967.

Nicolini, D. (2011), "Practice as the site of knowing: insights from the field of telemedicine", Organization Science, Vol. 22 No. 3, pp. 602-620.

Oldenburg, R. (1999), The Great Good Place, Da Capo Press, Cambridge.

Ostendorf, A. and Permpoonwiwat, C.K. (Eds), (2017), Workplaces as Learning Spaces - Conceptual and Empirical Insights, Innsbruck University Press, Innsbruck.

Presbitero, A. and Toledano, L.S. (2018), "Global team members' performance and the roles of cross-cultural training, cultural intelligence, and contact intensity: the case of global teams in IT offshoring sector", The International Journal of Human Resource Management, Vol. 29 No. 14, pp. 2188-2208.

Ramsamy-Prat, P. (2015), Le savoir relationnel du pharmacien. Scènes, discours et micro-actes professionnels, Thèse de doctorat, Conservatoire National des Arts et Mètiers, Paris.

Ramsamy-Prat, P. (2019), "Interaction with refugees”, in Merrill, B., Ninzinska, A. Galimberti, A. Eneau, J., Sanojca, E. and Bezzari, S. (Eds), Exploring Learning Contexts: Implications for Access, Learning Careers and Identities, University Rennes 2 / ESREA, Rennes, pp. 87-97. 
Rozkwitalska, M. (2017), "Intercultural interactions in traditional and positive perspectives", in Rozkwitalska, M., Sułkowski, L. and Magala, S. (Eds), Intercultural Interactions in the Multicultural Workplace: Traditional and Positive Organizational Scholarship, Springer, Switzerland, pp. 71-86.

Configuring learning spaces

Sannino, A., Engeström, Y. and Lemos, M. (2016), "Formative interventions for expansive learning and transformative agency", Journal of the Learning Sciences, Vol. 25 No. 4, pp. 599-633.

Schatzki, T.R. (2012), "A primer on practices: theory and research", in Higgs, J., Barnett, R., Billett, S., Hutchings, M. and Trede, F. (Eds), Practice-Based Education: Perspectives and Strategies, Sense Publishers, Rotterdam, pp. 13-26.

Seppänen, L. and Toiviainen, H. (2017), "Relational agency and the development of tools in service networks", in Edwards, A., (Ed.), Working Relationally In and Across Practices, A CulturalHistorical Approach to Collaboration, Cambridge University Press, Cambridge, pp. 153-171.

Shan, H. (2015), "Distributed pedagogy of difference: reimagining immigrant training and education", Canadian Journal for the Study of Adult Education, Vol. 27, pp. 1-16.

Shen, J. and Benson, J. (2014), "When CSR is a social norm: how socially responsible human resource management affects employee work behavior", Journal of Management, Vol. 42 No. 6, pp. 1723-1746.

Stetsenko, A. and Arievitch, I. (2004), "The self in cultural-historical activity theory", Theory and Psychology, Vol. 14 No. 4, pp. 475-503.

Toiviainen, H. (2007), "Interorganizational learning across levels: an object-oriented approach", Journal of Workplace Learning, Vol. 19 No. 4, pp. 343-358.

Toiviainen, H. and Vetoshkina, L. (2018), "Learning for the complex object of work in a digital printing network", Studia Paedagogica, Vol. 23 No. 2, pp. 25-42. doi: https://doi.org/10.5817/SP2018-2-3.

Toiviainen, H., Kerosuo, H., and Syrjälä, T. (2009), "Development Radar” the co-configuration of a tool in a learning network", Journal of Workplace Learning, Vol. 21 No. 7, pp. 509-524.

Toiviainen, H., Lallimo, J. and Hong, J. (2012), "Emergent learning practices in globalizing work: the case of a Finnish-Chinese project in a Finnish technology consulting firm", Journal of Workplace Learning, Vol. 14 No. 7/8, pp. 509-527.

Vygotsky, L.S. (1978), Mind in Society: The Development of Higher Psychological Processes, Harvard University Press, Cambridge, MA/London.

Wyn, J. (2013), "Young adulthood in Australia and New Zealand: pathways to belonging", in Helve, H. and Evans, K. (Eds), Youth and Work Transitions in Changing Social Landscapes, Tufnell Press, London, pp. 218-232.

\section{Further reading}

Kerosuo, H. and Engeström, Y. (2003), "Boundary-crossing and learning in creation of new work practice", Journal of Workplace Learning, Vol. 15 Nos 7/8, pp. 345-351.

\section{Corresponding author}

Hanna Toiviainen can be contacted at: hanna.toiviainen@tuni.fi

For instructions on how to order reprints of this article, please visit our website:

www.emeraldgrouppublishing.com/licensing/reprints.htm

Or contact us for further details: permissions@emeraldinsight.com 